\title{
KAJIAN PERUBAHAN IKLIM PADA PENENTUAN JADWAL TANAM CABAI DI KABUPATEN AGAM
}

\author{
Fadli Irsyad, Eri Gas Ekaputra' dan Assyaukani \\ Jurusan Teknik Pertanian, Fakultas Teknologi Pertanian, Universitas Andalas \\ Email: fadliirsyad_ua@yahoo.com
}

\begin{abstract}
ABSTRAK
Perubahan iklim erat kaitannya dengan perubahan pola hujan dan intensitas curah hujan yang berimbas kepada perubahan musim tanam. Kajian mengenai perubahan iklim perlu dilakukan untuk menentukan kapan musim tanam yang sesuai dengan proporsi pertumbuhan tanaman tersebut. Metode yang digunakan pada penelitian ini yaitu metode Man-Kendall untuk melihat apakah perubahan iklim dan curah hujan terjadi signifikan atau tidak. Metode Sens digunakan untuk melihat tingkat kemiringan perubahan tersebut yang kemudian digunakan untuk mengestimasi curah hujan bulanan pada tahun 2018 s/d 2019. Selanjutnya perhitungan neraca air dilakukan untuk melihat keseimbangan air yang akan digunakan sebagai pedoman penetapan jadwal tanam. Berdasarkan hasil penelitian pada wilayah ini, pada umumnya terjadi perubahan iklim pada setiap parameter iklim dengan tren positf kecuali pada parameter temperatur dan kecepatan angin yang mengalami tren negatif. Perubahan iklim terjadi pada tingkat probabilitas yang bervariasi berkisar antara $58 \%-100 \%$. Parameter iklim yang mengalami tren signifikan yaitu; kecepatan angin kumulatif dan maksimum dengan tren negatif pada probabilitas $100 \%$, kelembaban relatif rata-rata dan minimum dengan tren positif pada probabilitas sebesar $100 \%$, dan Evaporasi dengan tren positif pada probabilitas rata-rata $95 \%$. Berdasarkan perhitungan neraca air pada Stasiun Candung didapatkan jadwal tanam cabai yang tepat berada pada Bulan Februari. Sedangkan pada Stasiun Matur, jadwal yang tanam cabai dapat dilakukan pada Bulan Mei, dan Stasiun Gobah pada Bulan Januari. Diharapkan kepada petani cabai untuk menyesuaikan jadwal tanam cabai pada bulan tersebut agar mendapatkan kuantitas dan kualitas cabai yang diharapkan. Kata kunci-Tren, Perubahan Iklim, Probabilitas, Signifikan, Musim Tanam, Jadwal Tanam.
\end{abstract}

\section{PENDAHULUAN}

Perubahan iklim merupakan fenomena global yang kejadiannya telah dibuktikan pada berbagai penelitian mengenai tren data iklim salah satunya adalah peningkatan suhu. IPCC (2001) melaporkan tren suhu udara rata-rata global mengalami peningkatan sebesar $0,6^{\circ} \mathrm{C}$ selama abad ke-20. Perubahan iklim ini perlu mendapatkan perhatian serius karena keterkaitannya dengan sektor pertanian. Keberlangsungan ketersediaan hasil pertanian berpotensi terancam apabila perubahan iklim ini tidak disiasati dengan tepat.

Tanaman dalam pertumbuhannya sangat berkaitan dengan lingkungan khususnya iklim. Iklim merupakan salah satu faktor yang menentukan pertumbuhan tanaman karena tanaman membutuhkan unsur-unsur iklim dalam melakukan proses fisiologi selama pertumbuhannya. Iklim dengan kondisi tertentu dapat berdampak buruk terhadap tanaman karena mempengaruhi ketersediaan air tanah dan proses penyerbukan tanaman. Iklim dengan curah hujan yang tinggi menyebabkan ketersediaan air tanah melebihi dari yang dibutuhkan oleh tanaman. Akibatnya tanaman tidak dapat tumbuh dan berkembang dengan baik sehingga produksi menurun apabila tidak dilakukan pengelolaan yang tepat. Sebaliknya, tanaman dengan curah hujan yang sedikit maka yang terjadi juga hal yang sama yaitu terhambatnya pertumbuhan sehingga produksi juga rendah jika tidak dilakukan pengairan tambahan untuk mengatasi kekurangan ketersediaan air tanah.

Perubahan iklim mengakibatkan perubahan pola curah hujan. Perubahan pola curah hujan menyebabkan perubahan pola musim tanam. Fenomena mengenai perubahan pola musim tanam ini belum dikaji secara komprehensif untuk mendapatkan informasi dalam menetapkan jadwal tanam, sehingga masyarakat tidak memiliki kepastian dalam memulai penanaman. Akibatnya, dalam masa pertumbuhan akan menghadapi dinamika cuaca dengan curah hujan dan frekuensi yang menyimpang dari biasanya. Hal ini dapat berdampak buruk terhadap tanaman yang rentan terhadap curah hujan yang tinggi dan kelebihan air seperti tanaman cabai. Kondisi abnormal ini diindikasikan dengan peningkatan 
suhu dan intensitas curah hujan yang tinggi. Intensitas dan frekuensi curah hujan meningkat ketika memasuki bulan Oktober-Maret dan menurun pada bulan Juli-September. Akibatnya, tanaman cabai tidak dapat tumbuh dengan baik dibandingkan dengan bulan-bulan kering karena kadar air tanah tinggi dan banyak bunga-bunga yang berjatuhan sehingga proses penyerbukan terganggu. Selain itu, pada musim penghujan terdapat hama dan penyakit yang menyerang tanaman cabai yang disebabkan oleh drainase yang kurang baik dan udara yang lembab. Akibatnya, banyak masyarakat yang mengalami kegagalan selama masa panen cabai.

Produksi tanaman cabai pada bulan Oktober-Maret menurun dibandingkan pada bulan kering (Juli-September). Penurunan angka produksi tanaman cabai pada bulan tersebut dibuktikan berdasarkan data BPS Sumatera Barat (2014) produksi tanaman cabai berfluktuatif selama 2011 - 2013 dengan kecenderungan naik pada triwulan 2 dan 3, kemudian turun pada triwulan ke-4. Akibatnya, harga cabai melambung pada akhir dan awal tahun murah ketika panen pada pertengahan tahun. Ketidak-stabilan pasokan setiap musimnya jika dikaitkan dengan kebutuhan tehadap cabai yang relatif stabil setiap musimnya mengakibatkan peningkatan inflasi.

Sumatera Barat merupakan salah satu provinsi sentra cabai di Indonesia dengan menyumbang sebesar 5,62 \% dan merupakan provinsi tertinggi di luar pulau Jawa dalam hal kontribusi produksi cabai besar dari tahun 2010 - 2014 (Sekjen Kementan, 2015). Sebagian besar produksi cabai besar di Sumatera Barat berasal dari Kabupaten Agam dengan produksi terbanyak terdapat pada Kecamatan IV Angkek dan Matur. Meskipun demikian, masyarakat Sumatera Barat masih mengalami permasalahan dengan ketersediaan cabai dengan harga yang terjangkau pada rentang waktu yang cukup lama yaitu pada Oktober- Desember dan Januari-Maret. Maka dari itu perlu dilakukan penelitian dengan mengkaji sektor iklim yang merupakan penyebab terjadinya perubahan pola curah hujan seperti pergeseran musim hujan dan variabilitas curah hujan yang tinggi agar didapatkan informasi yang lebih akurat dalam menetapkan masa pertumbuhan tanaman cabai. Tujuan dari penelitian ini adalah mengkaji perubahan iklim dalam menentukan jadwal tanam cabai di Kecamatan IV Angkek dan Matur.

\section{METODOLOGI PENELITIAN}

\section{A. Waktu dan Lokasi Penelitian}

Penelitian ini dilaksanakan pada bulan April s/d Mei 2017, yang berlokasi di Kecamatan IV Angkek dan Matur dan pengolahan data dilakukan di Laboratorium Sumber Daya Lahan dan Air, Program Studi Teknik Pertanian, Fakultas Teknologi Pertanian, Universitas Andalas

\section{B. Bahan dan Alat}

Bahan yang digunakan dalam penelitian ini adalah data sekunder berupa data curah hujan ; stasiun Candung, stasiun Matur, dan stasiun Gobah. Sedangkan data iklim yang digunakan yaitu data klimatologi stasiun Candung dan stasiun Gumarang, rentang data yang digunakan yaitu 30 tahun yang dimulai pada 1986 s/d 2015, serta peta administrasi Kabupaten Agam. Data tersebut didapatkan dari Dinas Pengelolaan Sumber Daya Air (PSDA) Sumatera Barat dan Badan Meteorologi Klimatologi dan Geofisika (BMKG) Padang Pariaman. Alat yang digunakan pada penelitian ini adalah perangkat komputer yang disertai dengan aplikasi Microsoft Excel, ArcGIS 10.3, CROPWAT 8.0, GPS (Global Positioning System) untuk melakukan survey lapanganKamera digital untuk pengambilan dokumentasi.

\section{Prosedur Penelitian}

Analisis statistik yang digunakan adalah Man-Kendall. Penggunaan Man-Kendall dalam analisis ini bertujuan untuk melihat arah kecenderungan nilai variabel iklim seperti; curah hujan, temperatur, kelembaban relatif, kecepatan angin, dan evapotranspirasi terjadi secara signifikan atau tidak (Irsyad et al, 2011). Data time series curah hujan bulanan dan evapotranspirasi digunakan untuk mengestimasi kecenderungan komponen iklim dalam periode tertentu, analisis menggunakan metode Sen.

\section{Analisis Perubahan Iklim}

Data time series harian curah hujan $(\mathrm{R})$, temperatur $(\mathrm{T})$, kelembaban $(\mathrm{RH})$, kecepatan angin $(\mathrm{W})$, dan evapotranspirasi (ETo) pada setiap stasiun dijumlahkan menjadi data tahunan. Curah hujan ratarata wilayah penelitian dapat diketahui dengan menggunakan metode Poligon Thiessen, dengan persamaan: 
$P=\frac{\sum P i A i}{\sum A}=\sum_{i=1}^{n} W i P i$

$W i=\frac{A i}{\sum A i}$

Keterangan : $\bar{P}$ : Curah hujan rata-rata wilayah (mm/tahun); Wi: Ketetapan Thiessen; $P i$ : Curah hujan ke- $i$ pada stasiun penakar yang ada di $A i$; $A i$ : Luas daerah ke-i; A: Luas daerah total.

\section{Analisis Man-Kendall}

Analisis Man-Kendall dilakukan bertujuan untuk melihat arah kecenderungan perubahan curah hujan (tren). Tren dari data yang di uji dapat diketahui dengan menggunakan uji statistik Man-Kendall dengan persamaan :

$\mathrm{S}=\sum_{\mathrm{i}=1}^{\mathrm{n}-1} \sum_{\mathrm{j}=\mathrm{i}+1}^{\mathrm{n}} \operatorname{Sign}\left(\mathrm{x}_{\mathrm{j}}-\mathrm{x}_{\mathrm{i}}\right)$

Nilai S menentukan apakah terjadi atau tidaknya suatu tren dari data yang di analisis. Nilai S juga di interpretasikan sebagai sifat tren, apabila $\mathrm{S}=1$, maka data yang dianalisis mengalami kecenderungan perubahan yang meningkat, apabila nilai $\mathrm{S}=0$ maka tidak terdapat kecenderungan perubahan dari data tersebut, dan apabila nilai $S=-1$ maka terjadi kecenderungan perubahan yang menurun.

Selanjutnya, dilakukan perhitungan probabilitas untuk mengetahui tren terjadi secara signifikan

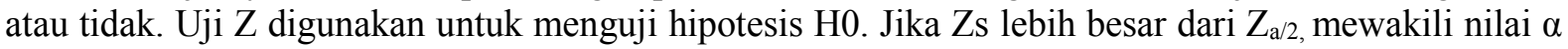
yang dipilih (misal $\alpha=5 \%$ dengan $Z_{0,025}=1,96$ ) maka hipotesis nol tidak valid dan menyiratkan bahwa tren signifikan.

$\mathrm{Z}=\left\{\begin{array}{cc}(S-1) / \sigma_{s} & \text { if } S>0 \\ 0 & \text { if } S=0 \\ (S+1) / \sigma_{S} & \text { if } S<0\end{array}\right.$

Pada perhitungan probabilitas diperlukan nilai varians dari data. Besarnya nilai Varians menerangkan besarnya keragaman data yang dianalisis. Varians dirumuskan dengan persamaan berikut:

$\sigma^{2}=\frac{n(n-1)(2 n+5)-\sum t_{i}(i)(i-1)(2 i+5)}{18}$

\section{Analisis Kemiringan Tren}

Analisis dilanjutkan dengan memperkirakan kemiringan dari kecenderungan data yang telah dianalisis menggunakan Man-Kendall. Metode yang digunakan yaitu Metode Sen. Perkiraan mengenai pola curah hujan perbulannya ke depan akan diketahui dengan mensubstitusikan besarnya nilai variabel (t) pada fungsi pada persamaan (5). Metode Sen akan digunakan untuk memprediksi nilai curah hujan bulanan dan evapotranspirasi bulanan selama empat musim yaitu pada tahun 2017 dan 2018 dengan mengasumsikan bahwasanya terjadi indeks pertanaman 2-3 kali dalam setahun.

\section{Analisis Ketersediaan Air}

Ketersediaan air dapat diartikan dengan besarnya debit air yang berada pada suatu wilayah dalam satuan waktu seperti; jam, hari, minggu, bulanan, tahunan, dan lain-lain. Pendugaan ketersediaan air dapat dilakukan dengan menggunakan beberapa metode. Pada penelitian ini analisis ketersediaan air dilakukan dengan menggunakan metode F.J. Mock. Penggunaan metode ini dilakukan karena data yang digunakan bukan dari data debit yang tercatat sepanjang tahun tetapi berdasarkan data curah hujan di daerah pengaliran sungai (Limantara 2010, dalam Budiman 2015).

Data-data yang digunakan dalam perhitungan ketersedian air menggunakan metode F.J. Mock yaitu data curah hujan bulanan (P), jumlah hari hujan (n), dan evapotranspirasi potensial (ETc). Pedugaan ketersediaan air pada Metode F.J. Mock memperhitungkan curah hujan, Evapotranspirasi potensial, dan karakteristik hidrologi daerah pengaliran sungai (Luneo et al., 2013). 


\section{Analisis Kebutuhan Irigasi dan Neraca Air}

Kebutuhan air irigasi dapat diketahui dengan memperhitungkan evapotranspirasi tanaman, jenis vegetasi, perkolasi dan lain-lain. Informasi mengenai kebutuhan air digunakan sebagai pembanding untuk menentukan apakah ketersediaan air yang ada mencukupi untuk melangsungkan pertumbuhan dan perkembangan tanaman yang ditetapkan.

Kondisi defisit air atau surplus air ditetapkan setelah analisis neraca air dilakukan. Analisis neraca air dilakukan untuk melihat kondisi ketersediaan air bulanan. Kondisi defisit air terjadi apabila ketersediaan air tidak dapat menggantikan kehilangan air yang diakibatkan oleh evapotranspirasi, perkolasi, dan kebutuhan konsumtif tanaman. Sedangkan kondisi surplus air merupakan suatu kondisi ketersediaan air mencukupi dan bahkan melebihi dari yang dibutuhkan untuk evapotranspirasi, perkolasi, dan lain-lain. Sehingga memungkinkan terjadi aliran permukaan.

Faktor-faktor yang digunakan dalam perhitungan dan analisis neraca air adalah ketersediaan air dari aliran air tanah (ketersediaan air tanah) dan kebutuhan air dari tiap daerah layanan (kebutuhan air tanah sendiri untuk industri, domestik serta irigasi persawahan).

Jadwal tanam ditentukan dengan memperhatikan neraca air tanaman dari masing-masing wilayah. Kebutuhan air tanaman dalam satu periode tanam menjadi acuan untuk menentukan jadwal tanam yang disesuaikan dengan ketersediaan air tanahnya. Jadwal tanam dipilih pada bulan surplus air sehingga tanaman akan aman dari defisit karena kebutuhan airnya dapat terpenuhi. Pola tanam ditentukan berdasarkan analisis pada CROPWAT.

\section{HASIL DAN PEMBAHASAN}

\section{A. Perubahan Iklim}

Pendugaan perubahan iklim dilakukan dengan menggunakan metode Man-Kendall. Jenis data yang di analisis yaitu data curah hujan dan data iklim. Mengenai jumlah stasiun, bentuk parameter yang digunakan dan hasil analisis dapat dilihat pada Tabel 1 dan Tabel 2.

Tabel 1. Data Hasil Pengujian Tren Iklim Menggunakan Man-Kendall.

\begin{tabular}{|c|c|c|c|c|c|c|c|c|c|c|}
\hline Parameter & Bentuk Data & Dari tahun & $\mathrm{n}$ & $\mathrm{S}$ & $\sigma \mathrm{s}$ & $\mathrm{Z}$ & $\alpha$ & $\mathrm{Z} \alpha$ & Tren & Probabilitas \\
\hline \multirow{4}{*}{ Temp } & Sum & 2009 & 5 & 0 & 4.08 & 0.00 & 0.05 & 0 & No Trend & $58 \%$ \\
\hline & Max & 2009 & 5 & -2 & 4.08 & -0.24 & 0.05 & 0.21 & Negatif & $58 \%$ \\
\hline & Ave & 2009 & 5 & -4 & 4.08 & -0.73 & 0.05 & 0.34 & Negatif & $63 \%$ \\
\hline & Min & 2009 & 5 & -5 & 4.08 & -0.98 & 0.05 & 0.52 & Negatif & $70 \%$ \\
\hline \multirow{4}{*}{ Wind } & Sum & 2009 & 7 & -12 & 6.66 & -1.65 & 0.05 & 3.06 & Negatif & $100 \%$ \\
\hline & Max & 2009 & 7 & -12 & 6.66 & -1.65 & 0.05 & 3.06 & Negatif & $100 \%$ \\
\hline & Ave & 2009 & 7 & 3 & 6.66 & 0.30 & 0.05 & 0.22 & Positif & $59 \%$ \\
\hline & Min & 2009 & 7 & 5 & 6.66 & 0.60 & 0.05 & 0.29 & Positif & $61 \%$ \\
\hline \multirow{4}{*}{ RH } & Sum & 2009 & 7 & -6 & 6.66 & -0.75 & 0.05 & 0.35 & Negatif & $64 \%$ \\
\hline & Max & 2009 & 7 & -5 & 6.66 & -0.60 & 0.05 & 0.29 & Negatif & $61 \%$ \\
\hline & Ave & 2009 & 7 & 12 & 6.66 & 1.65 & 0.05 & 3.06 & Positif & $100 \%$ \\
\hline & Min & 2009 & 7 & 16 & 6.66 & 2.25 & 0.05 & 31.92 & Positif & $100 \%$ \\
\hline \multirow{4}{*}{ Sun } & Sum & 2009 & 7 & 3 & 6.66 & 0.30 & 0.05 & 0.22 & Positif & $59 \%$ \\
\hline & Max & 2009 & 7 & 3 & 6.66 & 0.30 & 0.05 & 0.22 & Positif & $59 \%$ \\
\hline & Ave & 2009 & 7 & 3 & 6.66 & 0.30 & 0.05 & 0.22 & Positif & $59 \%$ \\
\hline & Min & 2009 & 7 & 3 & 6.66 & 0.30 & 0.05 & 0.22 & Positif & $59 \%$ \\
\hline \multirow{4}{*}{ Evapo } & Sum & 2009 & 7 & 15 & 6.66 & 2.10 & 0.05 & 16.60 & Positif & $100 \%$ \\
\hline & Max & 2009 & 7 & 9 & 6.66 & 1.20 & 0.05 & 0.85 & Positif & $80 \%$ \\
\hline & Ave & 2009 & 7 & 17 & 6.66 & 2.40 & 0.05 & 64.24 & Positif & $100 \%$ \\
\hline & Min & 2009 & 7 & 17 & 6.66 & 2.40 & 0.05 & 64.24 & Positif & $100 \%$ \\
\hline
\end{tabular}

Pada Tabel 1, nilai probabilitas temperatur rendah dengan nilai berkisar antara 58\% - 70\%. Data akumulasi temperatur (sum), tidak terjadi tren dengan probabilitas sebesar $58 \%$. Sedangkan jenis data lainnya cenderung mengalami tren negatif. Parameter kecepatan angin pada nilai sum dan max mengalami kecenderungan perubahan yang sangat signifikan dengan arah negatif pada tingkat probabilitas $100 \%$. Dibandingkan dengan nilai lainnya, yang memiliki nilai probabilitas rata-rata sebesar $60 \%$ dan arah kecenderungan positif. 
Parameter lama penyinaran mengalami kecenderungan positif pada setiap bentuk data. Namun kecenderungan ini tidak signifikan pada level kepercayaan 0,95, sehingga dikatakan tidak terjadi perubahan iklim pada parameter lama penyinaran. Hal tersebut juga terjadi pada parameter Evaporasi mengalami perubahan dengan arah positif pada setiap bentuk data namun, dengan tingkat signifikan yang sangat tinggi pada bentuk nilai akumulasi, rata-rata, dan maksimum dengan tingkat probabilitas sebesar $100 \%$. Walaupun nilai maksimum memiliki probabilitas sebesar $80 \%$, secara umum parameter evaporasi mengalami perubahan iklim.

Tabel 2. Data Hasil Pengujian Tren Curah Hujan Menggunakan Man-Kendall

\begin{tabular}{lllllllllll}
\hline Stasiun & Bentuk Data & Dari tahun & $\mathrm{n}$ & $\mathrm{S}$ & $\sigma \mathrm{s}$ & $\mathrm{Z}$ & $\alpha$ & $\mathrm{Z} \alpha$ & Tren & Probabilitas \\
\hline \multirow{6}{*}{ Candung } & Sum & 1986 & 29 & -49 & 53.31 & -0.90 & 0.05 & 0.45 & Negatif & $67 \%$ \\
& Max & 1986 & 29 & -75 & 53.31 & -1.39 & 0.05 & 1.37 & Negatif & $91 \%$ \\
& Ave & 1986 & 29 & -53 & 53.31 & -0.98 & 0.05 & 0.52 & Negatif & $70 \%$ \\
& Min & 1986 & 29 & -20 & 53.31 & -0.36 & 0.05 & 0.23 & Negatif & $59 \%$ \\
\hline \multirow{6}{*}{ Matur } & Sum & 1992 & 24 & 41 & 40.32 & 0.99 & 0.05 & 0.53 & Positif & $70 \%$ \\
& Max & 1992 & 24 & 39 & 40.32 & 0.94 & 0.05 & 0.49 & Positif & $69 \%$ \\
& Ave & 1992 & 24 & 41 & 40.32 & 0.99 & 0.05 & 0.53 & Positif & $70 \%$ \\
& Min & 1992 & 24 & -16 & 40.32 & -0.37 & 0.05 & 0.23 & Negatif & $59 \%$ \\
\hline \multirow{6}{*}{ Gobah } & Sum & 1990 & 26 & 52 & 45.37 & 1.12 & 0.05 & 0.71 & Positif & $76 \%$ \\
& Max & 1990 & 26 & 27 & 45.37 & 0.57 & 0.05 & 0.28 & Positif & $61 \%$ \\
& Ave & 1990 & 26 & 52 & 45.37 & 1.12 & 0.05 & 0.71 & Positif & $76 \%$ \\
& Min & 1990 & 26 & 125 & 45.37 & 2.73 & 0.05 & 350.12 & Positif & $100 \%$ \\
\hline
\end{tabular}

\section{B. Sen Methode}

Pada penelitian ini penggunaan metode Sen ditujukan untuk mengestimasi data curah hujan bulanan pada stasiun Candung, Matur, dan stasiun Gobah. Hasil estimasi nilai data ditampilkan dalam bentuk grafik pada Gambar 1.

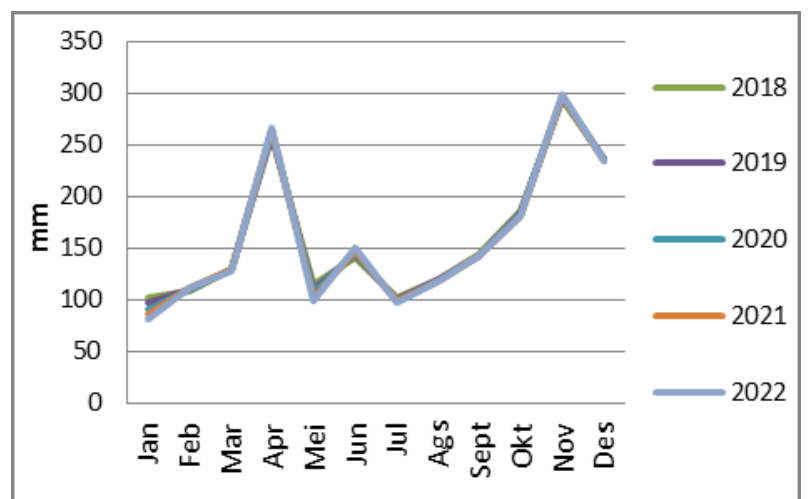

(a) Stasiun Candung

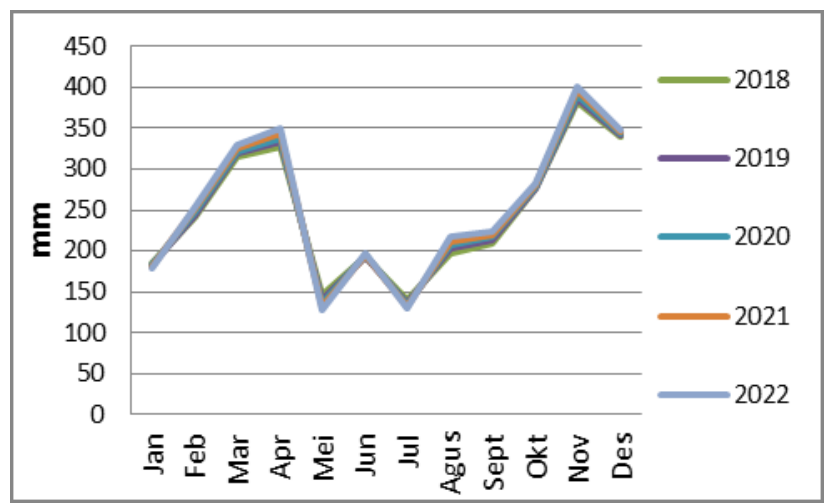

(b) Stasiun Matur

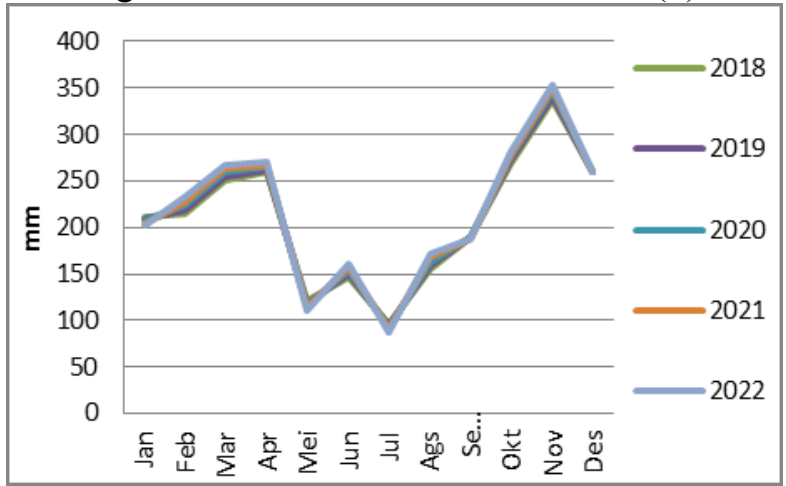

(c) Stasiun Gobah

Gambar 1. Grafik Hasil Pendugaan Curah Hujan Bulanan 
Pada Gambar 1, stasiun Candung (a) terdapat pola hujan yang relatif sama setiap tahun dengan memiliki dua puncak curah hujan yang terjadi pada bulan April dan bulan November. Bulan April memiliki rata-rata nilai curah hujan $262 \mathrm{~mm}$ sedangkan pada bulan November rata-rata $296 \mathrm{~mm}$. Sedangkan pada stasiun pengamatan curah hujan Matur (b) juga memiliki dua puncak curah hujan yang terjadi pada bulan April dan bulan November dengan nilai curah hujan rata-rata $338 \mathrm{~mm}$ dan $391 \mathrm{~mm}$. Stasiun Gobah (c) mengalami puncak curah hujan tertinggi pada bulan November dengan nilai curah hujan melebihi $350 \mathrm{~mm}$. Di daerah ini terdapat perbedaan yang cukup jauh antara puncak curah hujan.

\section{Ketersediaan Air}

Ketersediaan air pada penelitian ini menggunakan metode F.J Mock. Penggunaan metode ini didasarkan pada ketidaktersediaan data debit pada wilayah penelitian. Pada prinsipnya metode ini menggunakan keseimbangan hidrologi dimana curah hujan yang turun sebagian akan mengalami evapotranspirasi, dan sebagian lagi akan mengalir dan kembali ke sungai. Hasil analisis berupa data debit tersedia bulanan pada tahun 2018 s/d 2023. Data debit didapatkan dengan memperhitungkan parameter-parameter iklim yang diturunkan menjadi data debit bulanan. Data hasil pendugaan ketersediaan air ditampilkan pada Tabel 3, 4 dan 5.

Tabel 3. Hasil Pendugaan Ketersediaan Air Stasiun Candung Menggunakan Metode F.J Mock

\begin{tabular}{ccccccccccccc}
\hline \multirow{2}{*}{ Tahun } & \multicolumn{10}{c}{ Debit (Q) $\mathrm{m} /$ dtk } \\
\cline { 2 - 14 } & Jan & Feb & Mar & April & Mei & Jun & Jul & Agu & Sept & Okt & Nov & Des \\
\hline 2018 & 0.36 & 0.57 & 0.72 & 1.52 & 1.01 & 0.89 & 0.66 & 0.59 & 0.87 & 1.34 & 2.07 & 2.04 \\
2019 & 0.30 & 0.53 & 0.64 & 1.48 & 0.88 & 0.80 & 0.54 & 0.47 & 0.79 & 1.23 & 2.05 & 1.94 \\
2020 & 0.26 & 0.58 & 0.70 & 1.55 & 0.92 & 0.90 & 0.64 & 0.56 & 0.87 & 1.27 & 2.09 & 1.97 \\
2021 & 0.22 & 0.57 & 0.70 & 1.56 & 0.90 & 0.90 & 0.64 & 0.55 & 0.86 & 1.26 & 2.09 & 1.97 \\
2022 & 0.17 & 0.55 & 0.69 & 1.57 & 0.87 & 0.90 & 0.63 & 0.54 & 0.86 & 1.25 & 2.10 & 1.97 \\
2023 & 0.13 & 0.54 & 0.69 & 1.58 & 0.84 & 0.91 & 0.63 & 0.54 & 0.86 & 1.24 & 2.10 & 1.97 \\
\hline Rata-rata & 0.24 & 0.56 & 0.69 & 1.54 & 0.90 & 0.88 & 0.62 & 0.54 & 0.85 & 1.27 & 2.08 & 1.98 \\
\hline
\end{tabular}

Tabel 4. Data Hasil Pendugaan Ketersediaan Air Stasiun Matur Menggunakan Metode F.J Mock.

\begin{tabular}{|c|c|c|c|c|c|c|c|c|c|c|c|c|}
\hline \multirow{2}{*}{ Tahun } & \multicolumn{12}{|c|}{ Debit (Q) m/dtk } \\
\hline & Jan & Feb & Mar & April & Mei & Jun & Jul & Agu & Sept & Okt & Nov & Des \\
\hline 2018 & 1.95 & 3.51 & 4.45 & 5.15 & 2.81 & 2.76 & 2.16 & 2.56 & 2.86 & 3.81 & 5.89 & 5.82 \\
\hline 2019 & 1.93 & 3.55 & 4.52 & 5.25 & 2.78 & 2.75 & 2.13 & 2.22 & 2.94 & 3.85 & 5.96 & 5.88 \\
\hline 2020 & 1.91 & 3.59 & 4.59 & 5.35 & 2.74 & 2.73 & 2.10 & 2.27 & 3.01 & 3.90 & 6.04 & 5.94 \\
\hline 2021 & 1.89 & 3.63 & 4.65 & 5.45 & 2.71 & 2.72 & 2.07 & 2.32 & 3.09 & 3.94 & 6.11 & 6.00 \\
\hline 2022 & 1.87 & 3.67 & 4.72 & 5.55 & 2.67 & 2.70 & 2.03 & 2.36 & 3.17 & 3.98 & 6.19 & 6.06 \\
\hline 2023 & 1.85 & 3.70 & 4.79 & 5.65 & 2.64 & 2.69 & 2.00 & 2.41 & 3.24 & 4.02 & 6.26 & 6.11 \\
\hline Rata-rata & 1.94 & 3.54 & 4.50 & 5.22 & 2.79 & 2.75 & 2.13 & 2.37 & 2.97 & 3.84 & 5.94 & 5.86 \\
\hline
\end{tabular}

Tabel 5. Data Hasil Pendugaan Ketersediaan Air Stasiun Gobah Menggunakan Metode F.J Mock.

\begin{tabular}{llllllllllllll}
\hline \multirow{2}{*}{ Tahun } & \multicolumn{10}{c}{ Debit (Q) $\mathrm{m} / \mathrm{dtk}$} \\
& Jan & Feb & Mar & April & Mei & Jun & Jul & Agu & Sept & Okt & Nov & Des \\
\hline 2018 & 1.55 & 2.62 & 2.71 & 3.00 & 1.59 & 1.48 & 0.95 & 1.29 & 2.13 & 2.85 & 4.15 & 3.53 \\
2019 & 1.52 & 2.66 & 2.78 & 3.06 & 1.58 & 1.51 & 0.94 & 1.33 & 2.15 & 2.88 & 4.21 & 3.55 \\
2020 & 1.50 & 2.70 & 2.84 & 3.11 & 1.56 & 1.55 & 0.94 & 1.37 & 2.17 & 2.91 & 4.27 & 3.57 \\
2021 & 1.48 & 2.74 & 2.91 & 3.16 & 1.55 & 1.59 & 0.93 & 1.42 & 2.19 & 2.94 & 4.33 & 3.60 \\
2022 & 1.45 & 2.78 & 2.97 & 3.21 & 1.53 & 1.62 & 0.93 & 1.46 & 2.20 & 2.97 & 4.39 & 3.62 \\
2023 & 1.43 & 2.82 & 3.04 & 3.26 & 1.52 & 1.66 & 0.92 & 1.50 & 2.22 & 3.00 & 4.45 & 3.65 \\
\hline Rata-rata & 1.50 & 2.70 & 2.84 & 3.11 & 1.56 & 1.55 & 0.94 & 1.37 & 2.17 & 2.91 & 4.27 & 3.57 \\
\hline
\end{tabular}

\section{Kebutuhan Air Tanaman}

Kebutuhan air tanaman (ETc) yang dihitung adalah kebutuhan air selama masa pertumbuhan tanaman cabai dari pertumbuhan awal hingga akhir yang ditetapkan FAO selama 6 bulan. Kebutuhan air tanaman cabai pada penelitian ini dihitung pada setiap bulan tanam selama setahun sehingga didapatkan nilai kebutuhan air tanaman total pada pertumbuhan dengan masa yang berbeda (Gambar 2). 


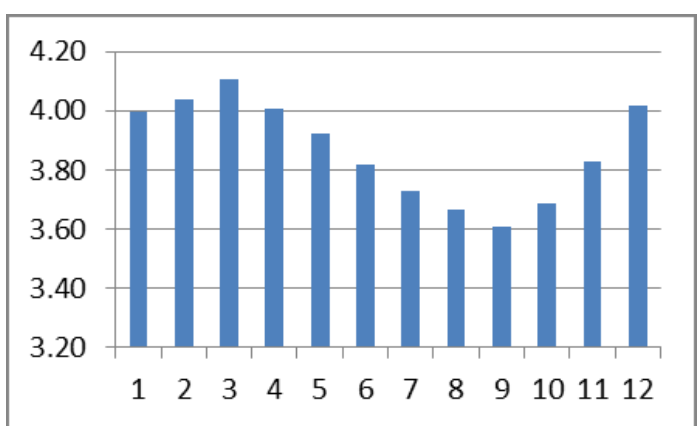

(a) Stasiun Candung

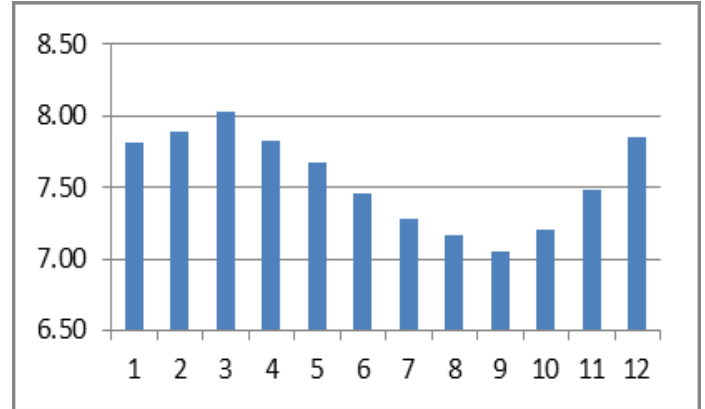

(b) Stasiun Matur

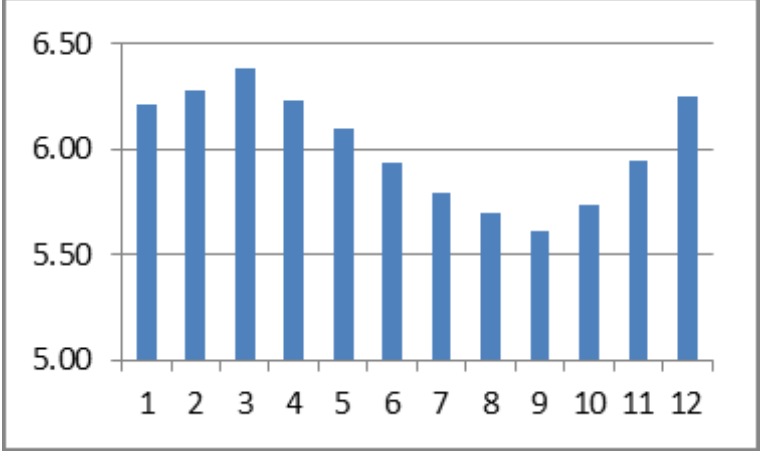

(d) Stasiun Gobah

Gambar 2. Diagram Kebutuhan Air Tanaman (ETc) Cabai

Kebutuhan air tanaman (ETc) cabai bervariasi setiap masa periode tanam. Hal ini dipengaruhi oleh besaran nilai Kc yang berbeda pada setiap tahapan pertumbuhan tanaman cabai dan perbedaan nilai ETo setiap bulan. Besaran nilai Kc menunjukkan fungsi besarnya kebutuhan air tanaman pada setiap tahapan pertumbuhan. Kebutuhan air (ETc) tanaman cabai pada lokasi stasiun Candung rata-rata $3,87 \mathrm{~m} 3 /$ dtk. Kebutuhan maksimum yaitu $4,11 \mathrm{~m} 3 /$ detik yang berada pada masa pertumbuhan Maret Agustus. Sedangkan kebutuhan air tanaman minimum yaitu 3,61 m3/detik berada pada musim tanam bulan September s/d Februari.

\section{E. Neraca Air}

Perhitungan neraca air dilakukan untuk melihat kondisi ketersediaan air dalam fungsinya untuk memenuhi kebutuhan air tanaman. Mengetahui nilai neraca air penting dilakukan agar dapat menjadi pedoman dalam menetapkan masa pertumbuhan tanaman. Hasil perhitungan neraca air ditampilkan dalam bentuk diagram pada Gambar 3, 4, dan 5. Diagram tersebut menampilkan hasil analisis dalam bentuk jumlah periode defisit, total defisit, total surplus, nilai defisit maksimum, dan nilai surplus maksimum.

Jumlah periode defisit merupakan banyaknya tahapan pertumbuhan yang mengalami defisit air pada satu musim tanam. Total Defisit merupakan jumlah defisit air selama satu musim tanam. Total Surplus merupakan adalah jumlah keseluruhan surplus air pada satu musim tanam. Sedangkan Nilai Defisit Maksimum merupakan nilai defisit maksimum yang terjadi dalam satu musim tanam dan Nilai Surplus Maksimum yaitu nilai maksimum surplus yang terjadi pada tiap-tiap tahapan pertumbuhan tanaman dalam satu musim tanam.

Pada Gambar 3 jumlah periode defisit terbanyak yaitu 3 periode yang terjadi pada bulan tanam Oktober, November dan Desember. Total defisit maksimum, total surplus maksimum, nilai defisit maksimum tertinggi, dan nilai surplus maksimum tertinggi terjadi pada bulan tanam yang sama yaitu bulan November. Sedangkan nilai total defisit minimum, nilai defisit maksimum terendah, dan nilai surplus terendah terjadi pada bulan tanam Februari, namun total surplus minimum terjadi pada bulan Januari. Dilihat secara keseluruhan berdasarkan hasil analisis, neraca air menunjukkan pola yang sama setiap tahun namun dengan nilai defisit dengan kecenderungan meningkat. 


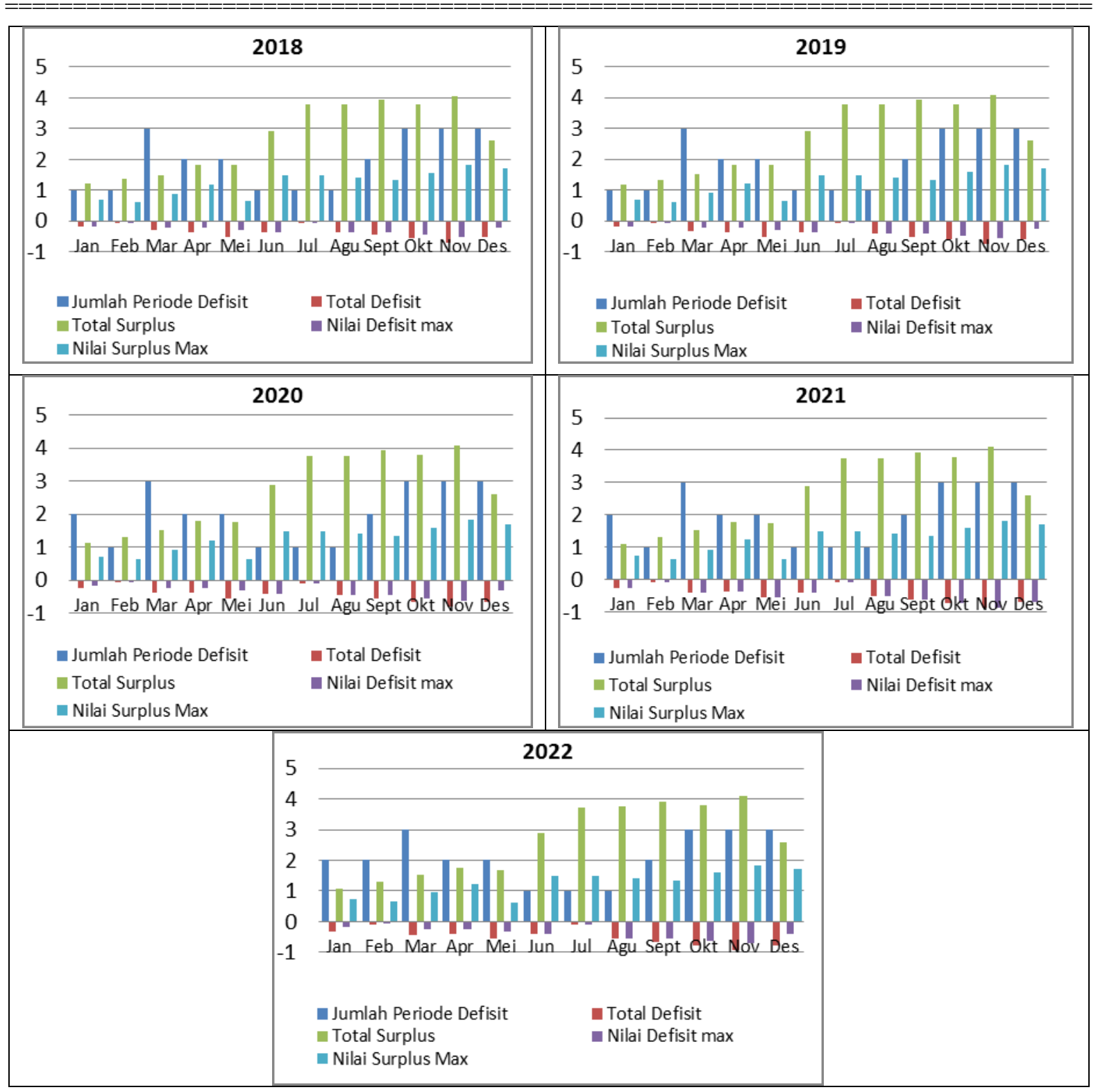

Gambar 3. Diagram Neraca Air Pada Setiap Bulan Tanam Stasiun Candung

Berdasarkan hasil analisis neraca air pada lokasi Stasiun Matur (Gambar 4), daerah ini memiliki ketersediaan air yang tinggi sehingga tidak terdapat satupun musim tanam yang mengalami defisit air berdasarkan bulan tanam yang dimulai pada tahun 2018 s/d 2022. Secara keseluruhan nilai Total Surplus tertinggi terjadi pada bulan tanam November sedangkan nilai Surplus terendah terjadi pada bulan Mei. Nilai Total Surplus mengalami peningkatan setiap tahun, namun berada pada pola yang sama.

Pada Gambar 5, neraca air tahun 2018 s/d 2022 menunjukkan bahwa terdapat sebanyak 5 musim tanam yang mengalami defisit air pada beberapa tahap pertumbuhan. Musim tanam yang mengalami defisit tersebut dimulai pada bulan tanam Februari s/d Juni. Diantara 5 musim tanam tersebut, musim tanam pada bulan tanam Mei mengalami Jumlah Defisit tertinggi. Sedangkan musim tanam yang tidak memiliki defisit air berada pada bulan tanam yang dimulai dari bulan Juli s/d Januari namun dengan rata-rata tingkat surplus yang cukup tinggi dengan nilai surplus maksimum yang terjadi pada bulan tanam Oktober. Total Surplus terendah pada kelompok musim tanam yang mengalami defisit berada pada bulan tanam Mei. Sedangkan nilai surplus terendah pada bulan yang tidak mengalami defisit air berada pada bulan Januari. 


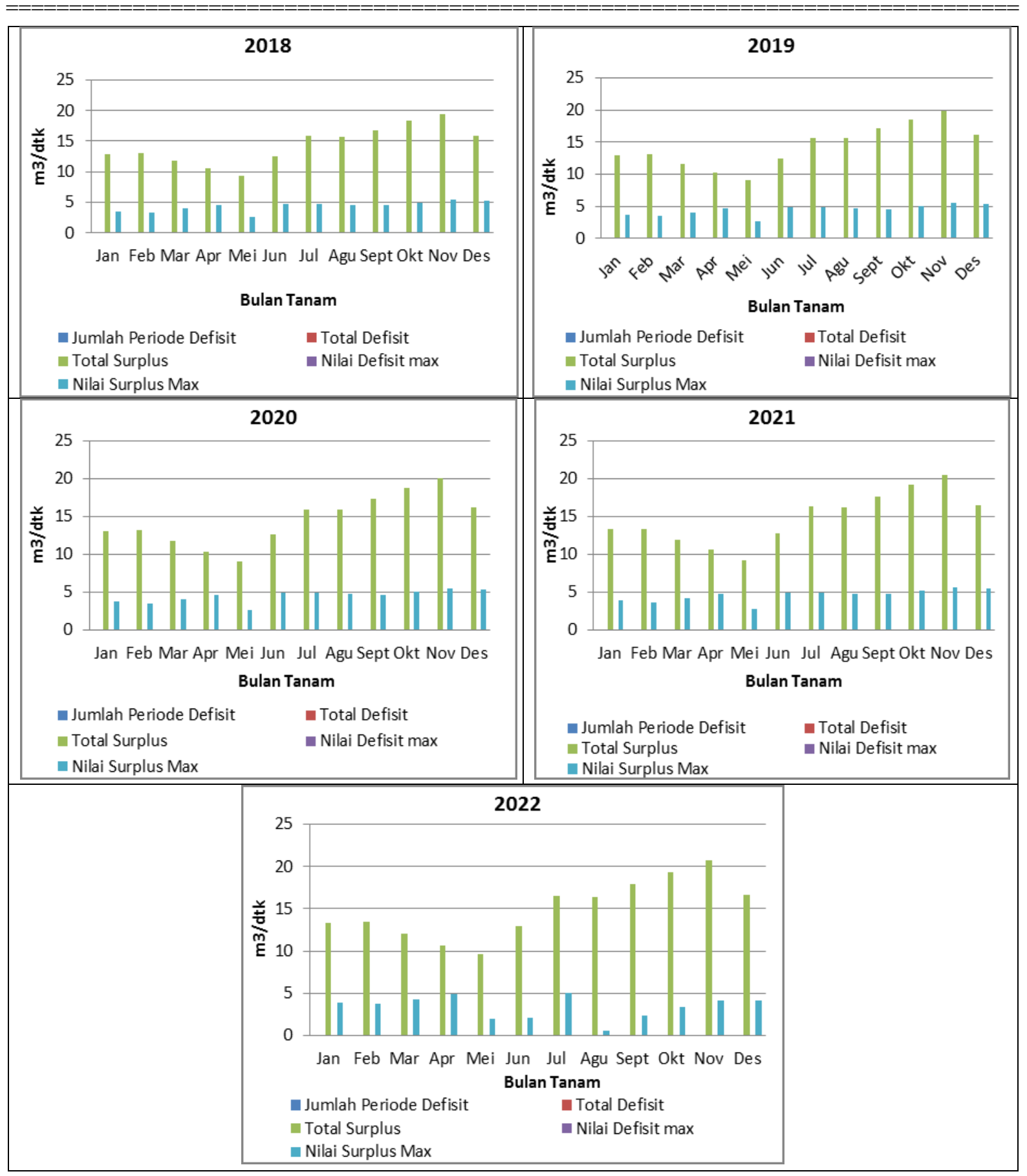

Gambar 4. Diagram Neraca Air pada Setiap Bulan Tanam Stasiun Matur

\section{F. Jadwal Tanam Cabai}

Jadwal tanam merupakan waktu yang ditetapkan untuk memulai usaha budidaya suatu tanaman pada sebidang lahan. Tanaman dalam pertumbuhan dan perkembangan nya harus berada pada masa yang tepat agar tercapai produksi yang lebih baik. Sehingga perlu dilakukan pengaturan jadwal tanam dengan mempertimbangkan faktor lingkungan.

Pengaturan jadwal tanam pada penelitian ini ditentukan berdasarkan hasil perbandingan ketersediaan air dengan kebutuhan air yaitu neraca air. Penetapan dilakukan dengan mengurutkan parameter berdasarkan faktor potensi pengaruh parameter terhadap hasil tanaman.parameter yang pertama yaitu (1) total defisit minimum, (3) total surplus minimum. Berdasarkan hasil neraca air maka jadwal tanam ditetapkan pada stasiun Candung didapatkan jadwal tanam yang sama setiap tahun dengan jadwal yang tepat berada pada bulan Februari. Sedangkan pada stasiun Matur jadwal tanam yang tepat berada pada bulan Mei dan Stasiun Gobah berada pada bulan Januari. 


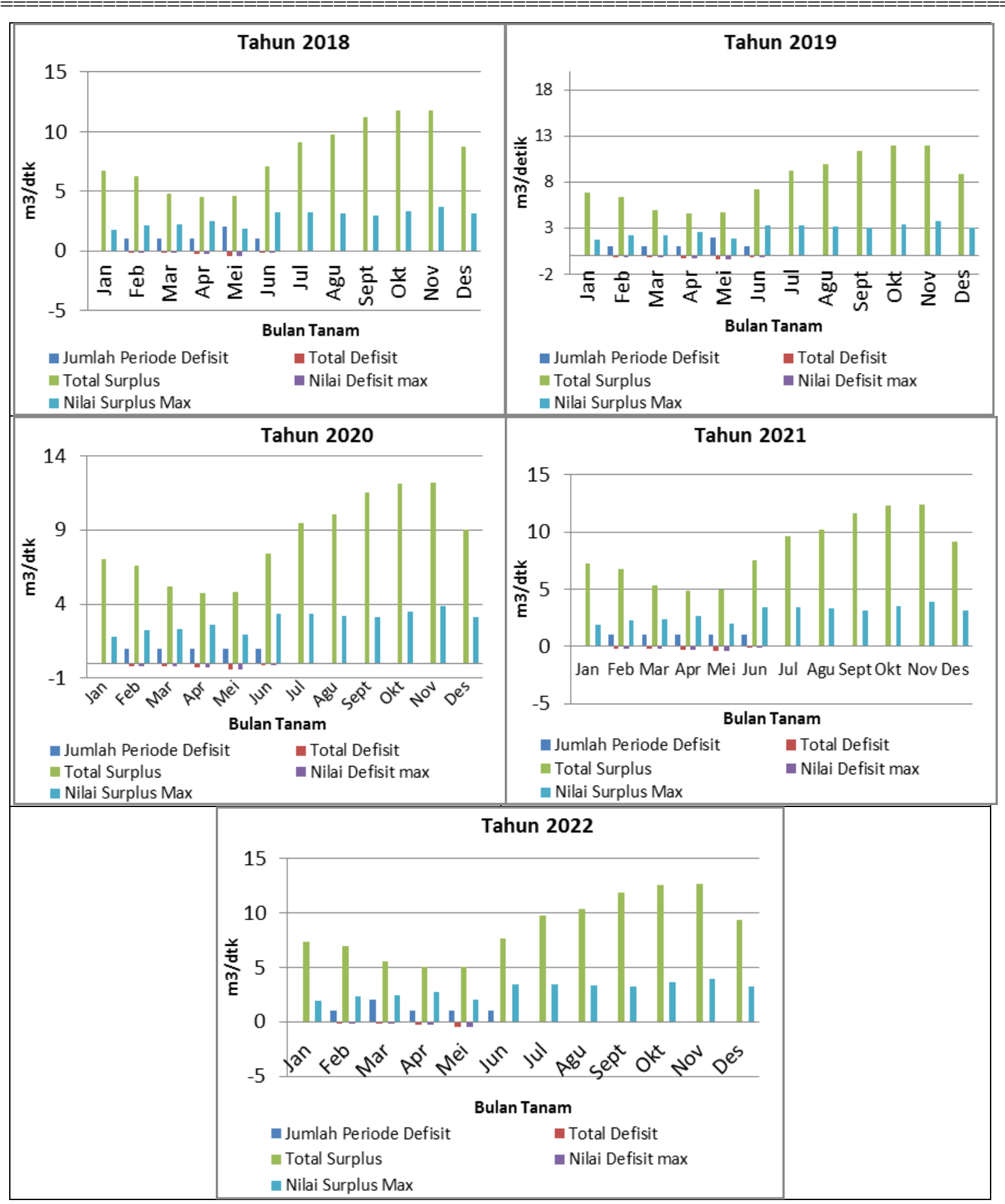

Gambar 5. Diagram Neraca Air Pada Setiap Bulan Tanam Stasiun Gobah

\section{G. Pelaksanaan Tanam Cabai Berdasarkan Kearifan Lokal}

Lahan pertanian pada Kecamatan IV Angkek dan Kecamatan Matur pada umumnya merupakan lahan tadah hujan. Masyarakat petani dalam melakukan proses budidaya sebagian didasarkan pada perkiraan musim hujan. Penggalian informasi mengenai prilaku masyarakat petani cabai dalam melaksanakan proses budidaya cabai khususnya dalam memulai penanaman cabai maka dilakukan survey ke lapangan dengan mewawancarai petani secara langsung. Wawancara dilakukan untuk mengetahui waktu penanaman cabai pada tahun 2016 dan tahun 2017. Data Hasil wawancara ditampilkan pada Tabel 6.

Pada Tabel 6, (A) menunjukkan sebanyak 13 data bulan tanam yang digabung ke dalam kelompok bulan tanam yaitu: DJF (Desember, Januari, Februari), MAM (Maret, April, Mei), JJA (Juni, Juli, Agustus), dan SON (September, Oktober, November). Berdasarkan data tersebut pelaksanaan bulan tanam umumnya dilakukan pada kelompok bulan DJF dengan jumlah 7 petani dari 13 petani. 
Kelompok bulan DJF memiliki jumlah bulan tanam terbanyak yaitu Januari berjumlah 4, diikuti oleh Februari berjumlah 2 selanjutnya Desember berjumlah 1. Kelompok bulan tanam JJA merupakan kelompok bulan tanam dengan jumlah petani yang menanam cabai terkecil yaitu sebanyak 1 pada bulan Agustus.

Tabel 6. Data Pelaksanaan Tanam Cabai di Kecamatan IV Angkek dan Kecamatan Matur

\begin{tabular}{ccccccccc}
\hline & \multicolumn{8}{c}{ Kelompok Bulan Tanam } \\
\cline { 2 - 9 } B. Tanam & \multicolumn{1}{c}{ DJF } & \multicolumn{9}{c}{ MAM } & \multicolumn{3}{c}{ JJA } & \multicolumn{3}{c}{ SON } \\
\cline { 2 - 9 } & A & B & A & B & A & B & A & B \\
\hline Jan & 4 & 2 & - & - & - & - & - & - \\
Feb & 2 & 2 & - & - & - & - & - & - \\
Mar & - & - & 1 & 1 & - & - & - & - \\
Apr & - & - & 1 & 3 & - & - & - & - \\
Mei & - & - & - & - & - & - & - & - \\
Jun & - & - & - & - & - & 1 & - & - \\
Jul & - & - & - & - & - & 1 & - & - \\
Agu & - & - & - & - & 1 & - & - & - \\
Sep & - & - & - & - & - & - & 3 & - \\
Okt & - & - & - & - & - & - & - & 1 \\
Nov & - & - & - & - & - & - & - & 1 \\
Des & 1 & 1 & - & - & - & - & - & - \\
\hline Jumlah & 7 & 5 & 2 & 4 & 1 & 2 & 3 & 2 \\
\hline Keterangan : & A = Data Kecamatan IV Angkek & & & & \\
& B = Data Kecamatan Matur &
\end{tabular}

Berdasarkan hasil analisis neraca air pada tahun 2016 dan 2017 pada wilayah kecamatan IV Angkek didapatkan jadwal tanam terbaik berdasarkan kriteria yang ditetapkan yaitu berada pada bulan Februari dan bulan Juli. Potensi jadwal tanam hasil analisis neraca air dengan praktik tanam cabai yang dilakukan oleh petani di Kecamatan IV Angkek tidak memiliki jarak yang relatif tidak terlalu jauh. Sehingga sangat memungkinkan untuk melaksanakan proses budidaya berdasarkan jadwal tanam tersebut dengan menunda melaksanakan penanaman selama lebih kurang 1 bulan.

Berdasarkan Tabel 6 pada wilayah Stasiun Matur (B) menunjukan bahwa kelompok bulan tanam terbanyak terdapat pada kelompok DJF berjumlah sebanyak 5 petani dari 13 orang. Selanjutnya diikuti oleh Kelompok MAM berjumlah 4 petani. Pada kelompok DJF jumlah petani penanam cabai relatif sama pada ketiga bulan tanam. Jika dikaitkan dengan hasil analisis neraca air tanaman cabai maka tanaman cabai tumbuh dan berkembang pada bulan-bulan yang basah yang relatif cukup tinggi. Sedangkan potensi jadwal tanam yang terbaik berada pada kelompok 2 yaitu bulan Mei. Hal ini tentu akan sulit bagi petani untuk berpindah pada jadwal tersebut dengan perbedaan bulan tanam yang cukup jauh bagi petani yang melaksanakan bulan tanam kelompok DJF.

\section{UCAPAN TERIMA KASIH}

Penulis ingin mengucapkan terimakasih kepada Fakultas Teknologi Pertanian Universitas Andalas yang telah mendanai penelitian ini melalui Program HIBAH Penelitian DIPA FATETA dan kepada seluruh pihak yang telah membantu terlaksananya penelitian ini.

\section{KESIMPULAN}

Berdasarkan hasil penelitian secara keseluruhan dapat disimpulkan bahwasanya :

1. Pada lokasi penelitian yaitu Kecamatan IV Angkek dan Kecamatan Matur berdasarkan stasiun curah hujan yang digunakan telah terjadi perubahan iklim pada; stasiun curah hujan Candung pada arah negatif namun tidak signifikan dengan rata-rata probabilitas yang rendah, stasiun curah hujan matur dengan arah perubahan yang positif namun tidak signifikan dengan rata-rata probabilitas 
rendah, dan stasiun curah hujan Gobah dengan arah yang positif dan probabilitas yang cukup tinggi dibandingkan dengan stasiun yang lain yang berkisar $61 \%-100 \%$.

2. Pada data Iklim terdapat tren negatif pada parameter temperatur namun probabilitas rendah. Pada parameter kecepatan angin terdapat kecenderungan negatif dengan probabilitas lebih tinggi. Namun pada parameter Kelembaban terjadi tren positif yang dominan berdasarkan rata-rata probabilitas. Lama penyinaran dan Evaporasi mengalami tren positif dan signifikan dengan probabilitas yang tinggi pada parameter Evaporasi, namun tidak signifikan pada lama penyinaran.

3. Berdasarkan hasil analisis neraca air pada Stasiun yang digunakan terdapat potensi jadwal tanam yang tepat yaitu; Pada Stasiun Candung tahun 2018 s/d 2023 bulan Februari, Stasiun Matur bulan Mei, dan Stasiun Gobah bulan Januari. Berdasarkan kebiasaan pada daerah Kecamatan IV Angkek tahun 2016 s/d 2017 penanaman cabai terbanyak dilakukan pada kelompok bulan DJF. Sedangkan pada daerah Kecamatan Matur, penanaman terbanyak dilakukan pada kelompok bulan DJF dan MAM.

\section{DAFTAR PUSTAKA}

[Balitbangtan] Badan Penelitian dan Pengembangan Pertanian. 2011. Pedoman Umum Adaptasi Perubahan Iklim Sektor Pertanian. 73 hal.

[BPS] Badan Pusat Statistik Sumatera Barat. 2014. Produksi Cabai Besar, Cabai Rawit, dan Bawang Merah tahun 2013. Berita Resmi Statistik. Sumatera Barat.

Budiman, Rijal. 2015. Analisis Potensi Sumberdaya Air Untuk Pengembangan dan Pembangkit Listrik Tenaga Mikro Hidro (PLTMH) Nagari Salareh Aia Kabupaten Agam. Fakultas Teknologi Pertanian. Universitas Andalas. Padang.

IPCC. 2001.Climate Change 2001: Impacts, Adaptation, And Vulnerability. 1042 hal.

Irsyad, Fadli., Saptomo, Satyanto Krido Budi., Setiawan, Indra. 2011. Analisis Perubahan Iklim Lokal Dan Debit Di Das Cidanau. Pascasarjana Institut Pertanian Bogor. Jurnal Agromet 25 (1): $17-23,2011$.

[Sekjen Kementan] Sekretariat Jenderal Kementerian Pertanian 2015. Outlook Cabai. Pusat Data dan Sistem Informasi Pertanian.79 hal. 